\title{
PELATIHAN DAN PENDAMPINGAN KOPERASI SERBA USAHA (SIMPAN PINJAM, PENGELOLAAN PASAR TRADISIONAL, DAN MINI MARKET)
}

\begin{abstract}
Multi-business Cooperation (Cooperation for Finance, Traditional Market Management and Convenience Store) is a program which consists of training, coaching and supervising to several cooperations of multi-business, finance and traditional market in Pal Satu Village, Tanjungpandan. Its partner is Regina Pacis Cooperation that has potentialities to improve economic development in family and community. However, there are several challenges which relate to management, financial access and member motivation. This program is aimed for: 1) to improve motivation of the cooperation's partners; 2) to improve the partner's understanding about cooperation planning; 3) to develop human resource in traditional market management; and 4) to expand networking in supporting creative economy. The results are: 1) the increasing of cooperation spirit in the members and society for supporting community development activities; 2) cooperation group and community have the ability in cooperation planning; 3) Regina Pacis Cooperation Tanjungpandan has obtained improvement in traditional market management; 4) network expansion in partnership; 5) Regina Pacis Cooperation Tanjungpandan has been becoming a role model for community based multi-business cooperation; and 6) the increasing of lecutrers and students participation from Belitung Management Academy in community empowerment.
\end{abstract}

Keywords :Training, Coaching, Supervising, Multi-business Cooperation

\begin{abstract}
Abstrak
Koperasi Serba Usaha (Simpan Pinjam, Pengelolaan Pasar Tradisional, dan Mini Market) adalah program pelatihan, pembinaan dan pendampingan pada koperasi koperasi serba usaha, simpan pinjam dan pengelolaan pasar di Desa Pal Satu Kecamatan/Kabupaten Tanjungpandan. Mitra program IbM ini adalah Koperasi Regina Pacis yang memiliki potensi untuk menopang ekonomi keluarga dan masyarakat. Akan tetapi, permasalahan sering muncul sebagaimana halnya koperasi di tempat lain, baik yang berkaitan dengan manajemen koperasi, akses terhadap pembiayaan, serta yang berkaitan dengan motivasi anggota koperasi. Kegiatan ini bertujuan untuk : 1) meningkatkan motivasi koperasi serba usaha mitra; 2) meningkatkan pemahaman mitra tentang perencanaan koperasi serba usaha; 3) meningkatkan kemampuan SDM dalam mengelola pasar tradisonal; serta 4) mengembangkan jejaring koperasi untuk menopang pengembangan ekonomi kreatif. Hasil dari kegiatan ini diantaranya adalah : 1) meningkatkan jiwa koperasipara anggota dan masyarakat sebagai upaya menunjang kegiatan pengembangan kelompok; 2) kelompok koperasi dan masyarakat memiliki kemampuan perencanaan koperasi; 3) meningkatnya kemampuan koperasi serba usaha Regina Pacis Tanjungpandan dalam melakukan pengelolaan pasar tradisional; 4) bertambahnya jaringan kerjasama koperasi; 5) model koperasi Regina Pacis Tanjungpandan dijadikan model pengembangan koperasi serba usaha yang berbasis pemberdayaan masyakarat; serta 6) mampu meningkatkan partisipasi dosen dan mahasiswa Akademi Manajemen Belitung dalam kegiatan pemberdayaan masyarakat.
\end{abstract}

Writer:

Hagoes Aryoko,

Tartini

Djunaedi Djafar

Correspondence:

hagoesAMB@gmail.com tartinikemal@gmail.com djunaedidjafar@gmail.com

Institution:

Akademi Manajemen Belitung

EKSIS

Vol XI No 2, 2016

ISSN:

1907-7513

$\underline{\text { http://ejournal.stiedewantara.ac.id/ }}$

Kata kunci: Pelatihan, Pembinaan, Pendampingan Koperasi Serba Usaha 


\section{A. PENDAhULUAN}

Salah satu upaya strategis dalam meningkatkan kesejahteraan masyarakat dengan memperkuat dasar kehidupan perekonomian dari sebagian terbesar rakyat Indonesia adalah melalui pemberdayaan koperasi. Ini mengingat besarnya potensi koperasi yang ditunjukkan oleh keberadaannya. Pemberdayaan koperasi akan mendukung peningkatan produktivitas, penyediaan lapangan kerja yang lebih luas, dan peningkatan pendapatan bagi masyarakat miskin.

Berbagai hasil pelaksanaan kebijakan, program dan kegiatan pemberdayaan koperasi antara lain adalah: (1) penyusunan berbagai rancangan peraturan perundangundangan, RUU tentang Koperasi, Penyusunan RPP tentang Kemitraan Pola Subkontrak; (2) pada tingkat operasional dalam upaya penguatan kelembagaan koperasi telah dikeluarkan Keputusan/Peraturan Menteri tentang Notaris sebagai Pembuat Akta Koperasi dan Penguatan Status Badan Hukum Koperasi dengan jumlah notaris yang telah ditetapkan sebagai Notaris Pembuat Akta Koperasidi seluruh Indonesia; (3) perkuatan kepada koperasi simpan pinjam/unit simpan pinjam koperasi melalui dukungan dana bergulir modal awal dan padanan, termasuk koperasi jasa keuangan syariah: (4) peningkatan kapasitas operasional kepada 50 lembaga penyedia jasa pengembangan koperasi atau Bussiness Development Services Providers; (5) penyelenggaraan berbagai diklat dalam rangka kewirausahaan dan membangun keunggulan kompetitif koperasi; (6) dukungan sertifikasi hak atas tanah bagi koperasi; (7) penumbuhan usaha baru melalui kemitraan dengan BUMN; (8) penggunaan Surat Utang Pemerintah (SUP-005) sebagai sumber pendanaan bagi koperasi dan (9) dukungan perkuatan kepada koperasisebagai pemicu untuk meningkatkan akses kepada sarana usaha, modal dan teknologi melalui sistem bergulir.

Selanjutnya, pemberdayaan koperasiyang dilaksanakan meliputi kegiatan: (1) peninjauan dan penyederhanaan berbagai peraturan serta prosedur perijinan, termasuk untuk memulai/mengembangkan usaha oleh koperasi; (2) pengembangan standardisasi dan sertifikasi sumberdaya manusia; (3) penyusunan lembaga advokasi koperasi; (4) perluasan skim kredit bagi koperasi; (5) penguatan jaringan pasar produk koperasi, termasuk pasar ekspor, melalui pengembangan lembaga pemasaran, jaringan usaha termasuk kemitraan usaha, dan sistem transaksi on line; (6) promosi produk koperasi; (7) peningkatan layanan informasi dan penguasaan teknologi tepat guna pada sentra koperasi; (8) pengembangan terpadu klaster usaha mikro; (9) pengembangan usaha ekonomi produktif bagi usaha mikro/sektor informal dalam rangka mendukung pengembangan ekonomi perdesaan dan penanggulangan kemiskinan; (10) penataan dan pembinaan organisasi serta modernisasi manajemen koperasi; dan (11) penumbuhan wirausaha baru.

Kondisi usaha yang dialami oleh koperasi ini memerlukan sentuhan dari pihak lain agar terjadi pengembangan usaha koperasi yang signifikan. Hal inilah yang menjadi dasar perlunya kegiatan pelatihan dan pendampingan koperasi serba usaha, yaitu Koperasi Regina Pacis Tanjungpandan kabupaten Belitung. Koperasi Regina Pacis telah berjalan selama 10 tahun. Sebagaimana halnya koperasi lainnya yang berkarakter dinamis, koperasi ini telah berperan dalam pengembangan diri melalui kegiatan serba usaha. Perannya telah dirasakan tidak hanya oleh anggota sendiri tetapi oleh masyarakat sekitar 
karena berhasil dalam menciptakan aktivitas yang produktif bagi para anggota dan masyarakat. Di sisi lain dapat memutus mata rantai kegiatan koperasi rentenir pada periode sebelumnya dan disamping menjadi role model bagi angkatan berikutnya.

Usia 10 tahun bukanlah sebentar jika koperasi memiliki target pengembangan usaha. Usia seperti diharapkan harus mampu menciptakan usaha koperasi yang lebih mapan untuk menopang ekonomi keluarga dan masyarakat. Akan tetapi, permasalahan sering muncul sebagaimana halnya koperasi di tempat lain, baik yang berkaitan dengan manajemen koperasi, akses terhadap pembiayaan serta yang secara non koperasi sepeti motivasi anggota itu sendiri.

Berikut ini adalah hasil identifikasi team terhadap permasalahan yang dihadapi dan harus dipecahkan oleh koperasi Regina Pacis Tanjungpandan dilihat dari berbagai sudut pandang yang relevan.

1. Belum memiliki perencanaan koperasi yang jelas sehingga target dan sasaran usaha belum memiliki arah kepada pengembangan usaha koperasi yang lebih mapan.

2. Manajemen keuangan yang belum memenuhi standar akuntansi paling tidak untuk standar koperasi. Laporan hanya dalam bentuk laporan secara global.

3. Upah kerja diberikan per tahun sehingga belum ada manajemen pembiayaan yang baik.

4. Pengelolaan koperasi simpan pinjam yang berorientasi pinjaman tujuan konsumtif bukan produktif. Hal ini menyebabkan lemahnya fungsi pengawasan. Koperasi tidak memiliki strategi pengawasan, hal ini bisa diakibatkan belum mantapnya perencanaan koperasi.
5. Kurangnya permodalan untuk ekspansi usaha. Hal ini disebabkan oleh lemahnya networking dengan instansi atau lembaga terkait baik lembaga pemerintah atau swasta.

6. Masih kurangnya motivasi koperasi untuk pengembangan usaha. Hal ini berakibat kegiatan usaha berjalan secara stagnan tanpa ada upaya untuk pengembangan skala usaha yang lebih besar.

7. Belum memiliki basecame tempat usaha yang tetap, karena masih menyewa. Hal ini sering mengganggu dalam kegiatan usaha koperasi..

\section{B. METODE}

Melalui kegiatan pelatihan dan pendampingan ini akan ditawarkan solusi bagi permasalahan-permasalahan yang telah dirumuskan di atas. Pendekatan yang ditawarkan bagi realisasi program ini adalah model pemberdayaan dengan langkah-langkah sebagai berikut : 1) Tahap Persiapan; 2) Tahap Assesment; 3) Tahap Perencanaan Alternatif Program atau Kegiatan; 4) Tahap Pemformulasian Rencana Aksi; 5) Tahap Pelaksanaan (Implementasi) Program atau Kegiatan; 6) Tahap Evaluasi; serta 7) Tahap Terminasi.

Pelaksanaan program ini memang dilaksanakan sebagai upaya pemberdayaan kelompok pemuda dalam bidang kewirausahaan melalui kegiatan pelatihan koperasi yang menitikberatkan kepada pengembangan usaha. Metode pelaksanaan program yang akan dilakukan adalah: (1) pelatihan manajemen usaha, (2) Pelatihan pengelolaan pasar, (3) pelatihan administrasi dan (4)pendampingan. Semua metode ini merupakan satu kesatuan dari program ini. 


\section{HASIL DAN PEMBAHASAN Kegiatan Pelatihan}

Kegiatan pengabdian ini telah dilaksanakan pada hari minggu, 5 Agustus s.d 21 Agustus 2016, yang bertempat di Aula SMP Regina Pacis Tanjungpandan. Kegiatan ini diisi dengan materi mengenai pengelolaan koperasi simpanpinjam, pengelolaan pasar tradisional, pengelolaan sampah limbah pasar yang berwawasan lingkungan, yang diikuti oleh pengurus Koperasi Regina Pacis Tanjungpandan berjumlah 9 orang, pengelola pasar berehun berjumlah 7 orang, dan pedagang pasar berehun berjumlah 16 orang.

Peserta pelatihan sangat antusias untuk mengikuti kegiatan ini, dibuktikan dengan kedatangan mereka tepat waktu. Antusiasme juga terlihat dalam mendengarkan penjelasan dari pemateri dan banyaknya pertanyaan yang diajukan seputar materi yang diberikan. Walaupun diakhir sesi kegiatan disediakan waktu khusus untuk Tanya jawab, namun beberapa peserta juga mengajukan pertanyaan disela-sela materi diberikan.

Materi yang diberikan 4 sesi dan diakhiri dengan sesi tanya jawab. Materi awal adalah tentang pengelolaan koperasi simpan pinjam disampaikan oleh Drs Hagoes Aryoko, M.Si. Materi kedua diberikan oleh Drs. Djunaedi Djafar, MM., MBA, tentang pengelolaan pasar tradisional yang berwawasan lingkungan, pentingnya kolam penetralisir air limbah pedangan pasar ikan, pengolahan sampah limbah pasar menjadi pakan ternak dan ikan serta menjadi pupuk kompos atau organik. Materi ketiga diberikan oleh Dra Tartini, M.Si. tentang pentingnya pedagang menjadi anggota koperasi

Sebelum memulai penyampaian materi, pemateri pertama terlebih dahulu memberikan pertanyaan sebagai pre-test. Pertanyaan pre-test diberikan untuk mengetahui sejauh mana pengetahuan dan pemahaman peserta dalam pengelolaan koperasi serba usaha, koperasi simpan pinjam, pengelolaan pasar tradisional, pengolahan limbah pasar ikan dan sayur. Pertanyaan yang diberikan meliputi apakah sudah mengetahui koperasi simpan pinjam, apakah sudah menjadi anggota koperasi simpan pinjam, apakah sudah menggunakan fasilitas pinjaman di koperasi. Jawaban pre-test dari peserta rata-rata sudah sebagian kecil menjadi anggota koperasi, hal inilah yang melatar belakangi peserta untuk mengikuti kegiatan pelatihan ini.

Pemateri kedua Drs. Djunaedi Djafar, MM., MBA, tentang pengelolaan pasar tradisional yang berwawasan lingkungan, pentingnya kolam penetralisir air limbah pedangan pasar ikan, pengolahan sampah limbah pasar menjadi pakan ternak dan ikan serta menjadi pupuk kompos atau 175rganic, terlebih dahulu memberikan pertanyaan sebagai pre-test. Pertanyaan pre-test diberikan untuk mengetahui sejauh mana pengetahuan dan pemahaman peserta dalam pengelolaan pasar koperasi serba usaha, sejauh mana pengelola pasar oleh mengolah limbah pasar ikan dan sayur. Pertanyaan yang diberikan meliputi apakah sudah mengetahui mengapa pasar dikelola koperasi, apakah sudah menjadi pedagang di pasar yang dikelola koperasi, apakah sudah mengelola limbah pasar dengan baik, bagaimana pengolahan sampah limbah pasar menjadi pakan ternak dan ikan serta menjadi pupuk kompos atau organik. Jawaban pre-test dari peserta rata-rata sudah sebagian kecil menjadi anggota koperasi, hal inilah yang melatar belakangi peserta untuk mengikuti kegiatan pelatihan ini.

Materi ketiga diberikan oleh Dra Tartini, M.Si. tentang pentingnya pedagang menjadi anggota koperasi, terlebih dahulu memberikan pertanyaan sebagai pre-test. Pertanyaan pre-test diberikan untuk mengetahui sejauh mana 
pengetahuan dan pemahaman peserta dalam seberapa pentinggya pedagang menjadi anggota koperasi, sejauh mana koperasi Regina Pacis mengembangkan usaha untuk mengelola mini market. Pertanyaan yang diberikan meliputi apakah sudah mengetahui mengapa menjadi anggota koperasi. Jawaban pretest dari peserta rata-rata sudah sebagian kecil memahami pentingya anggota koperasi, hal inilah yang melatar belakangi peserta untuk mengikuti kegiatan pelatihan ini.

Sesi Terakhir dari pelatihan ini adalah sesi tanya jawab, dimana para peserta secara aktif mengajukan pertanyaan yang berkaitan dengan pengelolaan koperasi simpan pinjam, pengelolaan pasar tradisional oleh koperasi, pembuatan kolam penetralisir air limbah ikan, pengolahan limbah pasar menjadi pupuk organik dan pakan ikan serta pakan ternak. Setelah Tanya jawab selesai, pemateri memberikan post test, untuk mengukur tingkat penerimaan dan pemahaman peserta selama mengikuti pelatihan ini. Dari hasil post-test, peserta sudah memiliki ide keuntungan jika menjadi anggota koperasi, pengolahan limbah pasar menjadi pupuk organik dan pakan ikan serta ternak.

Pendampingan

Administrasi dan Keuangan Mini Market

Kemampuan kelompok wirausaha koperasi dalam merancang administrasi dan laporan keuangan sangat diperlukan agar proses pelaksanaan koperasi bisa berjalan dengan efektif. Laporan keuangan dengan standar akuntansi mungkin tidak terlalu mendesak diperlukan bagi wirausahawaan pemula. Tetapi kemampuan pengelolaan administrasi dan keuangan sangat diperlukan dalam kegiatan koperasi paling tidak dapat mencatat arus kas dari proses usaha khususnya mini market yang di kelola Koperasi Regina Pacis.
Kegiatan ini dilaksanakan secara khusus untuk membina dan membekali pengelola agar mampu mengelola administrasi dan keuangan mini market. Dalam pelaksanaannya hanya seorang pengelola administrasi dan laporan keuangan yang dilatih untuk dapat mengembangkan pengelolaan administrasi dan laporan keuangan mini market. Pendamping pengelolaan mini market ini yang ditugaskan pada kegiatan ini adalah seorang guru akuntansi, pengelola bisnis center mini market SMK Negeri 1 Tanjungpandan dan wakil ketua koperasi Pegawai Negeri Wiyata Mandala yaitu Bpk Rayon Sihotang S.Pd. M.Si.

Mini market koperasi Regina Pacis Tanjungpandan baru berjalan sekitar satu setengah tahun yang di kelola secara manual. Pengelola mini market sebelum ada pelatihan pengelolaan administrasi dan keuangan mini market yang di laporkan hanya penjualan dan pembelian kemudian di selisihkan, tanpa melaporkan neraca dan laporan perubahan modal serta tidak ada catatan biaya-biaya lain yang dikeluarkan dalam pengelolaan mini market. Dengan adanya pelatihan pengelolaan administrasi dan keuangan mini market maka pengelola administrasi dan keuangan mini market telah dipersiapkan seperti laporan sisa hasil usaha, laporan perubahan modal, neraca, kartu sediaan barang serta notanota, kwitansi, kwitansi telah tersusun dengan rapi.

Pengelolaan administrasi dan laporan keuangan mini market masih dilakukan secara manual untuk rencana tindak lanjut berikutnya perlu diadakan pengelolaan administrasi dan laporan secara komputerisasi.

Pendampingan Pengolahan Sampah Pasar Menjadi Pakan Ikan dan Ternak

Pendampingan pengolahan sampah harus dilakukan beberapa kali supaya hasilnya maksimal. Kegiatan ini 
dilakukan terus-menerus dalam rangkaian kegiatan Enterpreneurship Motivation pengelolaan limbah menjadi pakan ternak dan ikan karena perlu uji coba, dan penelitian dengan baik dan benar. Fokus dari pendampingan ini adalah menambahnya wawasan tentang strategi merintis dan mengembangkan usaha bagi mitra dan pedagang pasar tradisional baik secara umum maupun secara khusus yang berkaitan pengelolaan barang-barang yang tidak berguna (sampah pasar) menjadi barang berguna (pakan ternak dan ikan) sehingga benar-benar siap dan layak digunakan. Pendamping pengelolaan ini yang ditugaskan pada kegiatan ini adalah seorang ketua kelompok tani Wana Lestari Desa Bantan sekaligus pembudidaya ikan yaitu Bpk Agus.

\section{E. PENUTUP}

Berdasarkan uraian pelaksanaan pelatihan dan pendampingan koperasi serba usaha dan pengelolaan pasar tradisional telah dilaksankan dengan baik. Hal ini karena: 1) pengelolaan pasar tradisional yang berwawasan lingkungan khususnya pengelolaan sampah telah tuntas dan menghasilkan pupuk organik serta pakan ternak dan ikan yang siap dijual dan digunakan; 2) adanya pelatihan pedagang pasar tradisional menjadi anggota koperasi pasar sehingga mereka siap menjadi anggota koperasi, 3) adanya pelatihan pengelolaan administrasi dan laporan keuangan mini market telah dilaksanakan sehingga pengelolanya dapat mengelola administrasi dan laporan keuangan seperti laporan sisa hasil usaha, perubahan modal dan neraca telah siap dengan baik sesuai standar ETAP.

Berdasarkan kesimpulan di atas maka dapat disarankan agar pelatihan pengelolaan koperasi simpan-pinjam perlu diadakan secara terus menerus. Selain itu pelatihan tentang Pengelolaan pasar tradisional yang berwawasan lingkungan perlu diadakan terus menerus terutama pendampingan pengeloaan sampah menjadi pakan ikan dan ternak dan menjadi pupuk organic karena member manfaat lebih kepada para pedagang di pasar.

\section{DAFTAR PUSTAKA}

DP2M Dikti (2009). Pedoman Pengabdian kepada Masyarakat 2009. Jakarta : Ditjen Dikti Depdiknas.

Rohaniyah, Suci (2005). Pola Pemberdayaan Pemuda dengan pelatihan Budidaya Ayam Arab di BPPLSP Regional III Jawa Tengah. Skripsi Tidak Diterbitkan Unnes Semarang.

LPPM UPI (2010). Pedoman Penelitian dan Pngabdian pada Masyarakat UPI 2010. Bandung : UPIZahro, Nafsiatuz dan Imam Baehaki. 2013. Pengaruh Kompetensi Tenaga Administrasi Sekolah terhadap Kinerja Pegawai Tata Usaha pada MTsN dan MAN di Kabupaten Kediri. Jurnal Ilmu Manajemen, REVITALISASI, Vol. 2.Nomor 2, Juni 2013. Diambil pada tanggal 25 April 2015 dari http://pascauniskakediri.ac.id/filesJurnalMhs/ Nafisatus \% 